\title{
除
}

AL-DZIKRA

Jurnal Studi Ilmu Al-Qur'an Dan Al-Hadits

http://ejournal.radenintan.ac.id/index.php/al-dzikra

Volume 13, No. 2, Desember Tahun 2019, Halaman 195 - 228

DOI://dx.doi.org/10.24042/al-dzikra.v13i2.4168

\section{METODE TAFSIR MAUḌU'Ī (TEMATIK): KAJIAN AYAT EKOLOGI}

\author{
Fauzan \\ UIN Raden Intan Lampung \\ fauzan@radenintan.ac.id \\ Imam Mustofa \\ IAIN Jurai Siwo Metro Lampung \\ imammustofa472@yahoo.co.id \\ Masruchin \\ UIN Raden Intan Lampung \\ masruchin80@radenintan.ac.id
}

\section{Abstract}

As a holy book, al-Qur'an has function as a law and a way of life for Muslims. In this context, Muslims in modern times have problem in understanding the whole contents of the Qur'an. Therefore, exegetes formulate a method of understanding the Qur'an in line with certain themes or so-called the Maudlu'i interpretation method. This article aims to describe the Maudlu'i interpretation, the problems of the Maudlu'i interpretation, and examples of the Maudlu'i interpretation. This literature review use descriptive qualitative method. The results of the study indicate that the interpretation of Maudlu'i is a method of interpretation that seeks to explain the contents of the Qur'an based on a particular theme. There are three focuses of Maudlu'i interpretation that developed in the 20th century, namely the Maudlu'i method of interpretation which focuses on terminology, 
the Maudlu'i method of interpretation which focuses on themes or topics in the Qur'an, and the Maudlu'i method of interpretation which focuses on one particular chapter in the Qur'an. Regardless of the dynamics of strengths and weaknesses, Maudlu'i interpretation is more suitable with the living conditions of modern-day Muslims. This study reveal that the Maudlu'i method of interpretation plays an important role in understanding the content of the Qur'an.

\section{Abstrak}

Sebagai kitab suci, al-Qur'an berfungsi sebagai undang-undang dan pedoman hidup umat Islam. Dalam konteks ini, umat Islam pada zaman modern seringkali kesulitan dalam memahami isi alQur'an secara keseluruhan. Oleh karena itu, para ahli tafsir kemudian merumuskan sebuah metode memahami al-Qur'an sesuai dengan tema-tema tertentu atau yang disebut sebagai metode tafsir Maudlu'i. Artikel ini bertujuan mendeskripsikan tentang Tafsir Maudlu'i, problematika tafsir Maudlu'i, dan contoh tafsir maudlu'i. Kajian pustaka ini dilakukan dengan metode deskriptif kualitatif. Hasil kajian menunjukkan bahwa tafsir Maudlu'i merupakan metode tafsir yang berusaha menjelaskan isi kandungan al-Qur'an berdasarkan tema tertentu. Metode tafsir yang berkembang pada abad 20 tersebut dibagi menjadi 3 kategori, yaitu tafsir maudlu'i yang fokus pada terminologi, tafir maudlu'i yang fokus pada tema atau topik dalam al-Qur'an, dan tafsir maudlu'i yang fokus pada satu surat tertentu dalam al-Qur'an. Terlepas dari dinamika kelebihan dan kekurangannya, tafsir Maudlu'i lebih sesuai dengan kondisi kehidupan umat Islam zaman modern ini. Hasil kajian menyimpulkan bahwa metode tafsir Mau'dlu'i memiliki peran penting dalam memahami isi kandungan al-Qur'an.

Kata Kunci: Metode Maụdu’̄, Tafsir dan Aplikatif.

\section{A. Pendahuluan}

Sebagai kitab suci, al-Qur'an melalui dialektika dengan realitas sosial senantiasa melahirkan pemahaman serta interpretasi baru yang akan terus berkembang. Hal ini mengisyaratkan perlunya metode-metode penafsiran yang membantu masyarakat dalam memahami isi kandungan al-Qur'an. Dengan demikian al-Qur'an sebagai kitab petunjuk tetap up to date sesuai dengan perkembangan kehidupan masyarakat 
kapanpun dan dimanapun. Sejumlah metode tafsir telah hadir dalam menjawab tantangan zaman. Dalam hal ini para ulama tafsir telah sepakat membagi metode penafsiran al-Qur'an menjadi empat, yaitu metode tahlik, metode ijmath, metode muqarran, dan metode maudu $u \imath$.

Dari ke empat metode tersebut, metode maud $u \grave{\imath}$ adalah metode yang terhitung muncul belakangan, meskipun pada masa klasik sebagian dari mufassir ada yang menerapkan metede ini, akan tetapi belum secara spesifik menggunakan metode maudu' sesuai dengan ketentuan yang ada. Metode ini terus berkembang khususnya pada abad 19-20 yang awal dikembangkan pada Fakultas Ushul al-Dīn (Teologi) di Universitas al-Azhar Kairo. Metode ini semakin menemukan bentuknya setelah al-Farmawi, yang juga sebagai guru besar pada Fakultas Ushul al-Dīn AlAzhar, menerbitkan bukunya Al-Bidayah fi al-Tafsir al-Maudlu' $i$ di Kairo pada tahun 1977.

Dalam perkembangan selanjutnya, dari langkah-langkah yang dilakukan oleh al-Farmawi yang banyak diikuti oleh generasi berikutnya sehingga muncullah beberapa karya tafsir yang membahas topik tertentu dalam al-Qur'an dengan menggunakan metode maud u $\iota$ ini, seperti "al-Insān fi al-Qur'ân" dan "al-Mar'ah fi al-Qur'ān" karya Abbas Mahmud al-'Aqqad, "al-Akhlāq fi alQur'ân" karya 'Abd al-A'la al-Sabzawari, "al-Yahūd fi al-Qur'ān”" karya Muhammad Izza Daruzah dan "al-Sabr fi al-Qur'an” karya Yusuf al-Qardhawi.

Sebagai sebuah metode penafsiran, metode maudu' mengundang perhatian khusus mulai dari konseptualisasi hingga pada tataran aplikasi dengan berbagai konsekuensinya diberbagai kalangan akademisi, pemerhati dan para pecinta lainnya. Fazlur Rahman melihat metode tafsir maudu' $\mathrm{l}$ ini sebagai satu-satunya cara yang bisa memberikan gambaran kepada pembaca akan kesatuan al-Qur'an dan pesan Tuhan pada manusia. ${ }^{1}$ Ia melihat bahwa metode tafsir maudu inini lebih dapat menangkap makna wahyu Tuhan lebih utuh dan komprehensif.

1 Fazlur Rahman, Major Themes of The Qur'an, 2nd ed. (Kuala Lumpur: Islamic Book Trust, 1999), hlm. xi 
Lebih lanjut, penelitian ini berusaha menyoroti metode tafsir maudu $u$ dari aspek historis, analisa teoritis, dan aplikasi melalui kajian pustaka, penulis mengkaji ayat-ayat al-Qur'an yang terkait dengan ekologi dengan pendekatan maudu't. Sehingga akan ditemukan apakah metode maudu' $\imath$ masih relevan ketika diterapkan untuk mengkaji sebuah ayat-ayat terhadap tema tertentu atau tidak.

\section{B. Hakekat dan Ruang Lingkup Tafsir Maudu'u'̄̄ \\ 1. Pengertian Tafsir Mauḍu'ī}

Istilah tafsir maudu $\imath$ terdiri atas dua kata, tafsir dan maud $u \hat{\imath}$. Kata tafsir dari sisi bahasa (etimologi) diambil dari akar kata al-fasr yang berarti: menjelaskan, menyingkap dan memperlihatkan makna yang logis (al-ibānah wa al-Kasyf wa İhār al-Ma'na al-Ma'qūl). ${ }^{2}$ Dari sini dapat dipahami bahwa secara bahasa kata tafsir mengandung arti menerangkan, menjelaskan serta mengungkapkan sesuatu yang belum atau tidak jelas maknanya. ${ }^{3}$ Sementara dari sisi istilah (terminologi) terdapat beberapa fariasi makna yang diberikan oleh para ulama. AlZarqani misalnya memaknai tafsir sebagai ilmu yang membahas al-Qur'an al-Karim dari sudut pengertian-pengertiannya sesuai dengan yang dikehendaki Allah dan kemampuan manusia biasa. ${ }^{4}$ Ibn 'Asyur (w. 1976 M) mendefinisikan tafsir sebagai ilmu yang membahas penjelasan makna-makna lafazh al-Qur'an, apa yang dapat dipetik (hikmah) darinya, baik secara ringkas atau luas. ${ }^{5} \mathrm{Al}-$ Zarkashi (w. $794 \mathrm{H}$ ) mendefinisikan tafsir sebagai suatu ilmu untuk memahami kitab Allah yang diturunkan kepada Nabi

${ }^{2}$ Manna' al-Qattan, Mabahith Fi “Ulum Al-Qur”an, (tt: ttp, tth), hlm. 323

3 Ibn Manzhur (w. 711. H) menyebut kata tafsir berasal dari kata fassara yang berarti menyingkap makna lafazh yang musykil (kasyf al-murad 'an al-lafzh al-musykil). Ibn Manzur, Lisan Al-'Arab, vol. Jilid V (Beirut: Dar Sadir, 1990), h. 55.; lihat juga al-Zarqani yang mendefinisikan kata tafsir dengan menerangkan dan menjelaskan (al-īdlāh wa al-tabyinn), 'Abd al-'Azhim al-Zarqani, Manahil Al- 'Irfan Fi 'Ulum Al-Qur'an, Jilid II, (Kairo: Dar Ihya alKutub al-'Arabiyah, tt), hlm. 3

4 al-Zarqani, Manahil Al- 'Irfan Fi "Ulum Al-Qur"an, hlm. 3

${ }^{5}$ Muhammad Thahir Ibn'Ashur, Al-Tahrir Wa Al-Tanwir, (Tunis: Dar al-Tunisiyah, tt), Juz I, hlm. 1 
Muhammad saw, dengan menjelaskan makna-makna dan mengeluarkan hukum-hukum serta hikmah-hikmahnya. ${ }^{6}$

Dari beberapa definisi di atas, dapat dipahami pengertian tafsir - sebagaimana disampaikan oleh Rif'at Syaukani Nawawi adalah ilmu yang membahas penjelasan tentang makna lafaz-lafaz serta maksud ayat-ayat al-Qur'an. Tafsir berusaha menjelaskan apa yang belum atau tidak jelas maksudnya supaya menjadi jelas. Menerangkan apa yang samar menjadi terang dan yang sulit dipahami menjadi mudah. ${ }^{7}$

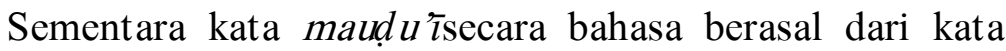
maudu', isim maf'ul dari fi'il madhiwadha'a yang memiliki makna beraneka ragam, yaitu: yang diletakkan, yang diantar, yang ditaruk, ${ }^{8}$ atau yang dibuat-buat, yang dibicarakan/tema/topik. ${ }^{9}$ Dalam konteks ini kata maudu $u \hat{\imath}$ dimaknai sebagai tema atau topik. Berangkat dari devinisi tersebut dapat dipahami bahwa tafsir maudu' $\imath$ adalah metode tafsir yang berusaha mencari suatu jawaban al-Qur'an tentang tema tertentu, sehingga tafsir ini juga diberi nama dengan tafsir tematik.

Adapun secara terminologi, para ulama tafsir memberikan definisi yang berbeda tentang istilah tafsir maud u'i. Ziyad Khalil Muhammad al-Daghawin mendefinisikan tafsir maudlu $`$ sebagai sebuah metode tafsir al-Qur'an dengan cara menghimpun ayatayat al-Qur'an yang mempunyai maksud yang sama dan meletakkannya dalam satu tema atau satu judul. ${ }^{10}$ Sementara Mustafa Muslim mendefinisikan tafsir maudu' $\imath$ sebagai sebuah ilmu yang membahas isu-isu dalam al-Qur'an melalui salah satu surat dalam al-Qur'an atau lebih. ${ }^{11}$ Dengan nada yang sama alFarmawi mendefinisikan tafsir maudu'i dengan menghimpun

${ }^{6}$ Burhan al-Din al-Zarkashi, Al-Burhan Fi "Ulum Al-Qur"an, Ibrahim Muhammad Abu Fadl (Ed), vol. 3, (Beirut: al-Maktaba al-'Airiyyah, tt), hlm. 13

7 Rif'at Syaukani Nawawi, Rasionalitas Tafsir Muhammad Abduh: Kajian Masalah Akidah Dan Ibadat, (Jakarta: Paramadina, 2002), hlm. 87

8 Muhammad Idris al-Marbawi, "Kamus Al- Marbawi", (Mesir: Mushthafa al-Babi al-Halabi, H 1350), hlm. 391

${ }^{9}$ Muhammad Idris al-Marbawi, "Kamus Al-Marbawi”, hlm. 1004

${ }^{10}$ Ziyad Khalil Muhammad al-Daghamin, Manhajiyyat Al-Bahth Fi AlTafsir Al-Mawdu'i Al-Qur'an Al-Karim, (Amman: Dar al-Bashir, 1995), hlm. 14

${ }^{11}$ Mustafa Muslim, Mabahith Fi Al-Tafsir Al-Mawdu'i (Dimashq: Dar al-Qalam, 2000), hlm. 16 
ayat-ayat al-Qur'an yang mempunyai maksud yang sama dalam arti sama-sama membicarakan satu topik masalah dengan menyusunnya berdasarkan kronologi serta sebab turunnya ayatayat tersebut. ${ }^{12}$

Dari pengertian tersebut dapat dipahami bahwa yang dimaksud dengan metode tafsir maudu' $\imath$ ini adalah tafsir yang menjelaskan beberapa ayat al-Qur'an mengenai sesuatu judul atau tema tertentu, dengan memperhatikan urutan tertib turunnya masing-masing ayat, sesuai dengan sebab turunnya yang dijelaskan dengan berbagai macam keterangan dari segala seginya, dan diperbandingkan dengan keterangan berbagai ilmu pengetahuan lain yang benar serta membahas topik yang sama sehingga lebih mempermudah dan memperjelas masalah. Jadi Dalam metode tafsir maud $u \hat{\imath}$ ini penafsiran tidak dilakukan ayat demi ayat, akan tetapi mengambil sebuah tema khusus dari berbagai macam tema doktrinal, sosial, dan kosmologis yang dibahas dalam al-Qur'an.

\section{Sejarah Perkembangan Tafsir Maựu'ì}

Sebagaimana dipahami bahwa istilah tafsir maudu'i merupakan istilah modern yang diperkenalkan pada abad 20 khususnya di Fakultas Ushul al-Dīn (Teologi) di Universitas alAzhar Kairo. ${ }^{13}$ Meskipun demikian, studi kritis tentang sejarah tafsir menunjukkan bahwa unsur-unsur tafsir maudut $u$ ini telah muncul jauh sebelum abad 20.

Dalam hal ini Mustafa Muslim, ${ }^{14}$ al-'Umarī, ${ }^{15}$ dan alDaghāmin ${ }^{16}$ menyebutkan bahwa ada pandangan sebagian ulama yang menganggap bahwa unsur tafsir maudut sudah ada sejak

${ }^{12}$ Abd. al-Hayy al-Farmawi, Metode Tafsir Maudu'i Suatu Pengantar, trans. Suryan A. Jamrah, (Jakarta: PT. Raja Grafindo Persada, 1996), hlm. 36

${ }^{13}$ Mustafa Muslim, Mabāhith Fi al-Tafsīr al-Maudu'u', (Dimashq: Dar al-Qalam, 2000), hlm. 17

${ }^{14}$ Mustafa Muslim, Mabāhith Fi al-Tafsìr al-Maudu' '̄̄, hlm. 17

${ }^{15}$ Ahmad Jamal al-Umari, Dirāsāt Fi al-Tafsir al-Maudu '̄ Li al-Qasās al-Qur'ānī, 2nd ed. (Cairo: Maktabat al-Khanji, 2001), hlm. 48

16 al-Daghamin, Manhajiyyat Al-Bahth Fi Al-Tafsir Al-Mawdu'i AlQur'an Al-Karim, hlm. 16 
masa Nabi. ${ }^{17}$ Salah satu argumennya adalah penyampaian wahyu al-Qur'an secara bertahap. Karena al-Qur'an diturunkan secara bertahap untuk mengatasi sebuah peristiwa, sehingga hal ini memunculkan gagasan tafsir maudu'ti. ${ }^{18}$ Namun argumen yang banyak dipakai didasarkan pada praktek Nabi yang senantiasa menafsirkan al-Qur'an dengan al-Qur'an (tafsir al-Qur'an bi alQur'an). Metode ini perlu mengkaji lebih dari satu ayat yang terkait dengan topik. Mustafa Muslim, misalnya, menunjukkan bukti yang mendukung pendapat ini dengan hadis riwayat dari alBukhari yang bersumber pada Ibn Mas'ud yang mengatakan: "Ketika turun ayat 82 surat Al-An'ām:

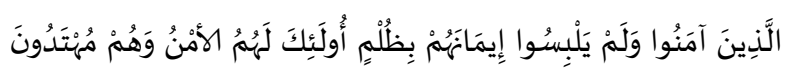

"Orang-orang yang beriman dan tidak mencampuradukkan iman mereka dengan kezaliman (syirik), mereka Itulah yang mendapat keamanan dan mereka itu adalah orang-orang yang mendapat petunjuk...". ${ }^{19}$

Para sahabat menjadi gelisah dan mereka menemui Nabi dan berkata: "Ya Rasulullah! Siapakah diantara kami yang tidak pernah berbuat salah?" Lalu Dia pun berkata, "bukan seperti itu, pernahkah kalian mendengar firman Allah

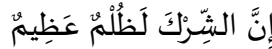 \\ “... Sesungguhnya syirik (musyrik) adalah dosa besar"."}

Sesungguhnya itu adalah syirik. ${ }^{21}$ Keterangan Ibnu Mas'ud tersebut menjelaskan bahwa Nabi SAW menjelaskan makna zulm yang dimaksud dalam QS. Al-An'ām ayat 82 tersebut adalah syirik sebagaimana dalam firman Allah QS. Luqman ayat 13.

Namun demikian al-Daghamin masih mempertanyakan anggapan sebagian orang yang melihat permulaan tafsir tematik pada generasi pertama. Menurutnya, pada waktu itu ayat-ayat alQur'an masih dalam proses pewahyuan secara bertahap, sehingga

${ }^{17}$ Muhammad Husayn al-Dhahabi, Al-Tafsir Wa Al-Mufassirun, 6.th., vol. Vol. 1 (Cairo: Maktabah Wahbah, 1995), hlm. 159

18 al-Daghamin, Manhajiyyat Al-Bahth Fi Al-Tafsir Al-Mawdu'i AlQur'an Al-Karim, hlm. 17

${ }^{19}$ QS. Al-An'ām [6]: 82.

${ }^{20}$ QS. Luqman [31]: 13.

${ }^{21}$ Muslim, Mabahith Fi Al-Tafsir Al-Mawdu'i, hlm. 17 
sulit untuk menentukan sejumlah ayat yang diwahyukan dalam satu tema tertentu. Meskipun dalam prakteknya Nabi SAW melakukannya, tetapi hal itu tidak berarti bahwa sebuah masalah ditangani secara rinci dan komprehensif sebagaimana yang harus dilakukan dalam tafsir tematik. ${ }^{22}$

Sementara itu ada beberapa ulama seperti Mustafā al-Sāwi al-Juwain̄̄ dan Ahmad al-Kūmi menyatakan bahwa sarjana pertama yang menggunakan metode tafsir ini adalah 'Amr ibn Bahr al-Jahiz $(200 \mathrm{H})$ yang telah mengumpulkan ayat-ayat yang terkait dengan satu topik tertentu seperti yang telah dilakukannya dalam kitab "Al-Nār fi al-Qur'an". Al-Juwayni menjelaskan bahwa meskipun al-Jahiz tidak sepenuhnya menggunakan metode tafsir maudu'i sebagaimana yang dipahami saat ini, namun secara faktual dia bisa dianggap sebagai orang pertama yang menggunakan metode ini".

Selain pendapat di atas, ada sebagian ulama yang melihat bahwa tafsir tematik sudah ada sejak abad ke-2 Hijriyah. Hal ini nampak dari beberapa contoh karya seperti Muqātil bin Sulaimān al-Balkhi (150. H) dalam kitab "Al-Aṣbah wa al-Nąāir", Abū 'Ubayd al-Qāsim bin Sallām (224. H) dalam kitab "Al-Nā sikh wa al-Mansū kh", 'Āli ibn al-Madan̄̄ (234. H) dalam kitab "Asbāb alNuz̄il', Ibnu Qutaibah (276. H) dalam kitab "Ta'w̄l Mushkīl alQur'an", Abū Bakr al-Jassās (370. H) dalam kitab "Ahkām alQur'ân", al-Raghib al-lsfahāni (502. H) dalam kitab "al-Mufradāt Fi Ghan̄b al-Qur'àn", al-'Izz ibn 'Abd al-Salām (660. H) dalam kitab "Majāz al-Qur'ān" dan Ibn al-Qayyim (751. H) dalam kitab “Aqsām al-Qur'ān" dan "Amthāl al-Qur'ān" .

Namun, pendapat ini tidak diterima dengan baik oleh sebagian ulama lain yang berpendapat bahwa karya-karya tersebut hanya sebagian dari bentuk tafsir maudut. Meskipun karya-karya tersebut terkait dengan ayat-ayat yang relevan tetapi tidak dibuat untuk menafsirkan ayat-ayat secara menyeluruh. Al-Khalidi memberikan alasan bahwa karya-karya tersebut tidak sesuai

${ }^{22}$ al-Daghamin, Manhajiyyat Al-Bahth Fi Al-Tafsir Al-Mawdu'i AlQur'an Al-Karim, hlm. 17

23 al-Daghamin, Manhajiyyat Al-Bahth Fi Al-Tafsir Al-Mawdu'i AlQur'an Al-Karim, hlm. 18

${ }^{24}$ Muslim, Mabahith Fi Al-Tafsir Al-Mawdu'i, hlm. 20-21 
dengan metode sistematis tafsir maudu $\imath^{25}$ Dengan kata lain, karya-karya tersebut tidak dimaksudkan untuk menafsirkan ayat tetapi hanya untuk menjelaskan makna kata tertentu, untuk menguraikan isu-isu tertentu atau untuk membuat sebuah putusan hukum. Akan tetapi secara faktual, karya-karya tersebut telah membantu para mufassir dalam menafsirkan al-Qur'an. ${ }^{26}$ Oleh karena itu dapat dikatakan bahwa para mufassir al-Qur'an pada masa klasik belum menerapkan metode tafsir maudu $u$, tetapi karya-karya mereka secara kebetulan sesuai dengan beberapa elemen mauduti. Oleh karena itu, dapat dikatakan bahwa pada masa itu belum ada kebutuhan untuk menerapkan metode tafsir maudut, mungkin karena belum adanya tafsir maudu $\imath$ yang sistematis pada masa itu. ${ }^{27}$ Jika kita melihat pada karya-karya tafsir pada masa itu, kita akan melihat bahwa secara umum karyakarya pada masa itu belum menerapkan metode tafsir maudu $u$, namun karya-karya tersebut tidak jauh dari tiga pendekatan yang disebutkan sebelumnya.

Tafsir maudu $u$ sebagai suatu ilmu atau sebuah metode penafsiran tersendiri adalah istilah yang baru muncul pada abad ke-14 Hijriyah, tepatnya ketika untuk pertama kalinya Prof. Dr. Ahmad Sayyid al-Kumy, Ketua Jurusan Tafsir pada Fakultas Ushul al-Dīn Universitas al-Azhar, Mesir, memasukkannya sebagai materi kuliah. $^{28}$ Metode ini semakin menemukan bentuknya setelah al-Farmawi, yang juga menjabat guru besar pada Fakultas Ushul al-Dīn Al-Azhar, menerbitkan bukunya AlBidayah fi al-Tafsir al-Maudlu'i di Kairo pada tahun 1977.

Pendekatan tafsir maudu $u \hat{\imath}$ pada masa modern muncul di akhir abad ke-19 dengan munculnya karya Muhammad Abduh. Dia dianggap sebagai salah seorang yang memperkenalkan aliran

25 Salah 'Abd al-Fatah al-Khalidi, Al-Tafsīr Al-Maudu'̄ Bayn AlNazariyyah Wa Al-Tațbīq, (Jordan: Dar al-Nafas'is, 2001), hlm. 37

${ }^{26}$ al-Daghamin, Manhajiyyat Al-Bahth Fi Al-Tafsir Al-Mawdu'i AlQur'an Al-Karim, hlm. 17

27 al-Daghamin, Manhajiyyat Al-Bahth Fi Al-Tafsir Al-Mawdu'i AlQur'an Al-Karim, hlm. 19

${ }^{28}$ Khālid 'Abdurrahmān al-'Ak, Al-Furqān Wa Al-Qur'ān, (Beirut: Dār al-Hikmah, t.th), hlm. 61 
pemikiran sosial ( 'aqliyyah ijtimī'iyyah) dalam tafsir. ${ }^{29}$ Meskipun ia tidak menulis secara sistematis dengan metode tafsir maudu $\imath$, tetapi ia menekankan pentingnya pendekatan ini terhadap koherensi kontek (siȳa $q$ ) dalam surat-surat al-Qur'an. ${ }^{30}$ Unsur hubungan (koherensi) adalah bagian dari tafsir maudut. Mengikuti jejak Muhammad Abduh, muncul tafsir-tafsir yang menekankan pentingnya mengumpulkan ayat-ayat al-Qur'an dalam satu topik yang sama. Karya-karya tersebut menyatu dengan pendekatan tafsir adabi ijtimat (tafsir sosio-sastra). ${ }^{31} \mathrm{Di}$ antara ahli tafsir ini adalah Amin al-Khūli, 'Aisyah binti 'Abd alRahmān - yang lebih dikenal dengan nama samarannya Bint alShati', dan Sayyid Qutb. Dalam buku Manāhij Tajdìd, al-Khūli sebagaimana dicatat Jansen, menekankan pada para ulama yang akan menulis tafsir al-Qur'an untuk memperhatikan semua ayat al-Qur'an ketika berbicara tentang suatu masalah, dan tidak membatasi dirinya hanya menafsirkan satu pernyataan al-Qur'an dan mengabaikan pernyataan lainnya dalam tema yang sama. ${ }^{32}$ Dalam pembacaan al-Daghāmin, al-Khūli memahami tafsir maudu' $\imath$ dalam dua jenis: pertama, secara khusus mengkaji tentang al-Qur'an yang fokus pada topik-topik terkait dengan alQur'an seperti wahyu dan kumpulan wahyu al-Qur'an. Kedua, mengkaji tentang al-Qur'an itu sendiri dengan melihat kata-kata dan kosakatanya, petunjuk-petunjuk Qur'ani, dan bagaimana kata-kata tersebut digunakan dalam al-Qur'an. ${ }^{33}$

Sementara penekanan Bint al-Shāti' terhadap pentingnya tafsir maudu' Qurān al-Karim". Dia menjelaskan bahwa dasar tafsir adabi adalah pemahaman atas topik (tanāwul al-maudu' /comprehension of topic) di mana seorang mufassir berusaha

\footnotetext{
${ }^{29}$ al-Khalidi, Al-Tafsīr Al-Maudu'̄̄ Bayn Al-Nazariyyah Wa Al-Taṭbīq, hlm. 25

${ }^{30}$ al-Umari, Dirasat Fi Al-Tafsir Al-Mawdu'i Li Al-Qosos Al-Qur'ani, hlm. 56

${ }^{31}$ al-Umari, Dirasat Fi Al-Tafsir Al-Mawdu'i Li Al-Qosos Al-Qur'ani, hlm. 56

${ }^{32}$ J.J.G Jansen, The Interpretation of the Qur'an in Modern Egypt, 2nd ed. (Leidin: E.J. Brill, 1980), hlm. 67

${ }^{33}$ al-Daghamin, Manhajiyyat Al-Bahth Fi Al-Tafsir Al-Mawdu'i AlQur'an Al-Karim, hlm. 23-24
} 
memahami tujuan al-Qur'an, dan ini dimulai dengan mengumpulkan semua surat dan ayat-ayat tentang sebuah topik yang dipelajari. ${ }^{34}$

Adapun Qutb, di antara karya-karya besarnya yang berkaitan dengan topik ini adalah "FīZilāl al-Qur'ân", "Mashāhid al-Qiyāma fi al-Qur'ān" dan "al-Taswīr al-Fann̄ fì al-Qur'ān". ${ }^{35}$ Ia juga menekankan pentingnya tema-tema dalam al-Qur'an sebagaimana dalam pernyataannya: '... siapapun yang mendalami al-Qur'an akan melihat bahwa setiap surah memiliki identitas khusus (shakhsiyyah mutamayyizah), ... untuk itu (sebuah surat) merupakan topik utama atau topik-topik yang sangat terkait dengan tujuan tertentu. ${ }^{36}$ Tentang hal ini bisa dilihat dalam karyakarya Qutb di mana ia menghubungkan tema-tema dalam surat dengan sebuah penjelasan yang diambilnya dari ayat al-Qur'an, sebab turunnya wahyu ( $a s b \bar{a} b$ al-nuzū $)$, dari hadis, dan dari apa yang diterima (transmited) dari para sahabat dan tabi'in. ${ }^{37}$ Dalam perkembangan selanjutnya, muncullah beberapa karya tafsir yang membahas topik tertentu dalam al-Qur'an seperti "al-Insān fi alQur'ān" dan "al-Mar'ah fi al-Qur'ān” karya Abbas Mahmud al"Aqqad, "al-Akhlāq fi al-Qur'ān" karya "Abd al-A'la alSabzawari, "al-Yahūd fi al-Qur'ān" karya Muhammad Izza Daruzah dan "al-Sabr fi al-Qur'an" karya Yusuf al-Qardhawi. ${ }^{38}$

Melihat perkembangan karya tafsir maud u' $\imath$ yang ada, para ulama kemudian mengklasifikasikan karya tafsir maud $u \imath$ tersebut dalam tiga kategori:

a. Tafsir maudu $u$ ¿ yang fokus pada terminologi.

Pada kategori ini, seorang mufassir akan menelusuri kata atau istilah tertentu dalam al-Qur'an, kemudian ia mengumpulkan

${ }^{34}$ al-Umari, Dirasat Fi Al-Tafsir Al-Mawdu'i Li Al-Qosos Al-Qur'ani, hlm. 62

35 al-Umari, Dirasat Fi Al-Tafsir Al-Mawdu'i Li Al-Qosos Al-Qur'ani, hlm. 58

$27-29$

${ }^{36}$ Sayyid Qutb, Fi Zilāl al-Qur'ān (Beirut: Dar al-Syuruq, 1987), hlm. hlm. 60

${ }^{37}$ al-Umari, Dirasat Fi Al-Tafsir Al-Mawdu'i Li Al-Qosos Al-Qur'ani,

${ }^{38}$ Muslim, Mabahith Fi Al-Tafsir Al-Mawdu'i, h. 20-21. Lihat juga: alDaghamin, Manhajiyyat Al-Bahth Fi Al-Tafsir Al-Mawdu'i Al-Qur'an AlKarim, hlm. 23-24 
semua ayat yang mencakup istilah dan turunannya tersebut, kemudian dia mencoba menyimpulkan petunjuk (dalā lāt) istilah dari perspektif al-Qur'an. Misalnya, istilah-istilah seperti ummā, șadaqa, jihād dan kitāb. Seorang mufassir hanya fokus pada makna tanpa mengkaji dan menginterpretasikan secara komprehensif ide dan ajaran yang ditemukan dalam ayat-ayat dengan istilah yang relevan. Karya tafsir klasik yang mendekati kategori ini, antara lain misalnya buku-buku tentang "Ghan̄b alQur'ān" dan "Al-Ashbāh wa al-Nąāìi". ${ }^{39}$ Al-Dāmighāni (478. H) dalam kitabnya Iṣ lāh al-Wujūh wa al-Nąă 'ir, misalnya, mengkaji istiah khayr dan menyimpulkan bahwa istilah ini memiliki delapan aspek (wujuh) yaitu harta (māl/wealth), keyakinan (Imān), terbaik (af̣̂̄ā), kebaikan ('āfiya), penghargaan (ajr/reward), makanan (ta'àm/food) dan kemenangan (zafrivictory). Dalam hal ini ia memberikan bukti dari ayat-ayat al-Qur'an yang mendukung temuannya ini. ${ }^{40}$

b. Tafsir maudut yang fokus pada tema atau topik dalam alQur'an.

Seorang mufassir akan menentukan sebuah tema atau topik tertentu yang ada dalam al-Qur'an dalam berbagai cara pembahasan. Pada kategori ini, mufassir akan menelusuri topik melalui surat al-Qur'an dan memilih ayat-ayat yang relevan. Kemudian, setelah mengumpulkan ayat-ayat, memahami makna dan mengulas ayat-ayat tertentu, ia kemudian menyimpulkan unsur topik pembahasan dan mengaturnya, membaginya dalam bab dan sub bab. ${ }^{41}$ Contoh karya tafsir klasik yang mendekati kategori ini adalah "I'jāz al-Qur'ān" karya Abu Bakar al-Baqilani, "al-Nāsikh wa al-Mansūkh fì al-Qur'ān" karya Abū 'Ubayd alQāsim bin Sallām dan "Ahkām al-Qur'ān" karya Abū Bakr alJassās. Sementara contoh karya tafsir modern yang mengkaji tema tertentu dalam al-Qur' an seperti "al-Insān fi al-Qur'ān" dan "alMar'ah fi al-Qur'ān" karya Abbas Mahmud al-'Aqqad, "al-Akhlāq fi al-Qur'ān" karya "Abd al-A'la al-Sabzawari, "al-Yahūd fi alQur'ân" karya Muhammad Izza Daruzah dan "al-Sabr fi al-Qur'an" karya Yusuf al-Qardhawi.

\footnotetext{
${ }^{39}$ Muslim, Mabahith Fi Al-Tafsir Al-Mawdu'i, hlm. 39

${ }^{40}$ Muslim, Mabahith Fi Al-Tafsir Al-Mawdu'i, hlm. 24

${ }^{41}$ Muslim, Mabahith Fi Al-Tafsir Al-Mawdu'i, hlm. 27
} 
c. Tafsir mauduiyang fokus pada satu surat tertentu dari alQur'an.

Katogori ini lebih terbatas dari kategori kedua. Pada tipe ketiga ini seorang mufassir mengkaji ide-ide pokok yang dibahas dalam surat tertentu, ide-ide yang menjadi topik pembahasan (mihwar al-tafsìr al-mauduî). Meskipun karya tafsir pada masa klasik tidak ada yang mendekati kategori ini, beberapa karya tafsir dapat dikaitkan dengan jenis ketiga ini, seperti tafsir al-Razi yang berjudul "al-Tafsìr al-Kabìr" (606. H), karya al-Biqa'i yang berjudul Nażm al-Durar fi Tanāsub al-Āyāt wa al-Suwar (885. H). Sementara karya tafsir pada masa modern, Muhammad al-Ghazali menganggap bahwa Muhammad Abd Allah al-Darrāz sebagai salah seorang yang menyoroti kategori ketiga ini dalam karyanya al-Naba 'al-'Azī $m .^{42}$ Meskipun dalam karyanya ini al-Darrāz hanya memfokuskan tafsirnya pada surah al-Baqarah. ${ }^{43}$ Sementara Sayyid Qutb dalam kitab FïZilāl al-Qur'ann dapat dikatakan sebagai karya tafsir terlengkap dalam kategori tafsir maud $u ` \imath$ yang ketiga ini.

Mencermati ketiga kategori tafsir maudu $u \grave{\imath}$ tersebut di atas, Ziyad al-Daghāmin tidak sependapat untuk memasukkan kategori pertama sebagai bagian dari metode tafsir maud $u \hat{\imath}$. Ia berargumentasi bahwa studi tentang terminologi dalam al-Qur'an tidak bisa komprehensif karena hanya mencakup beberapa terminologi yang sering disebutkan dalam al-Qur'an. Adapun kata-kata yang terjadi sekali dalam al-Qur'an seperti maskh, masad dan amshāj, kajian terhadap beberapa kata tersebut hanya fokus pada kemunculan tunggalnya, sehingga tidak termasuk dalam konsep kumpulan ayat-ayat yang relevan. Alasan lainnya adalah pembahasan kata-kata ini tidak bermaksud untuk mengkaji topik secara menyeluruh, tetapi tujuannya adalah untuk sampai pada arti yang sebenarnya dari sebuah terminology. ${ }^{44}$

${ }^{42}$ Muhammad al-Ghazali, Nahw Tafs'ir Mawdu'i Li Suwar Al-Qur'an (Beirut: Dar al-Syuruq, 2002), hlm. 28

${ }^{43}$ Muhammad 'Abd Allah al-Darraz, Al-Naba' Al-'Azim, (Alexandria: Dar al-Murabitun, 1997), hlm. 89

44 al-Daghamin, Manhajiyyat Al-Bahth Fi Al-Tafsir Al-Mawdu'i AlQur'an Al-Karim, hlm. 13 


\section{Prosedur Operasional Metode Tafsir Maud u`}

Al-Farmawi dalam bukunya Metode Tafsir Maudu ù Suatu Pengantar memberikan penjelasan yang rinci tentang langlahlangkah penerapan atau cara kerja tafsir maudut. Berikut akan disampaikan beberapa langkah tersebut: Pertama, menentukan tema masalah yang akan dibahas; Kedua, menghimpun ayat-ayat yang berkaitan dengan tema tersebut; Ketiga, menyusun sekuensial ayat sesuai dengan kronologis turunnya, disertai pengetahuan tentang asbab al-nuzul;Keempat, memahami munasabah (korelasi) ayat-ayat tersebut dalam surahnya masingmasing; Kelima, menyusun kerangka pembahasan yang sempurna (outline); Keenam, melengkapi pembahasan dengan hadis-hadis yang relevan; dan Ketujuh, meneliti ayat-ayat tersebut secara keseluruhan dengan cara menghimpun ayat-ayatnya yang mempunyai pengertian sama, atau mengkompromikan antara yang 'am (umum) dan yang khash (khusus), mutlak dan muqayyad (terikat), atau yang pada lahirnya bertentangan, sehingga kesemuanya bertemu dalam satu muara, tanpa perbedaan atau pemaksaan. $^{45}$

Sebagai contoh seorang mufassir menghimpun sejumlah ayat yang bersifat mutlak seperti:

$$
\text { وَأَحَلَّ اللَّهُ الْبَيْعَ وَحَرَّمَ الَِِِّا }
$$

“...padahal Allah telah menghalalkan jual beli dan mengharamkan riba" $" 46$

Dan ayat yang bersifat muqoyyad seperti:

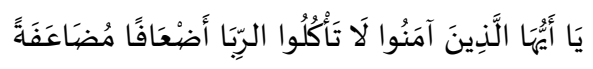

"Hai orang-orang yang beriman, janganlah kamu memakan riba dengan berlipat ganda". ${ }^{47}$

Jika mufassir tersebut hanya mengambil pengertian ayat yang muqayyad semata dan mengesampingkan ayat yang bersifat mutlak. Maka ia akan sampai pada kesimpulan bahwa riba yang diharamkan adalah riba yang berlipat ganda. Sedangkan riba yang tidak berlipat ganda tidak haram. Penafsiran

\footnotetext{
45 al-Farmawi, Metode Tafsir Maudu'i Suatu Pengantar, hlm. 61

${ }^{46}$ Al-Baqarah: 275

${ }^{47}$ Ali Imran: 130
} 
semacam ini bisa menimbulkan kekeliruan, sebab pengertian ayat yang mutlak tidak selamanya mengikuti ayat yang muqayyad, dan sebaliknya. Dalam hal ini untuk menentukan pengertian ayat yang mana harus diambil penafsiran harus melihat pada masa dan konteks turunnya ayat tersebut, serta harus mengetahui proses serta tahapan penetapan hukum oleh al-Qur'an.

Pada contoh kasus di atas, seorang penafsir harusnya mengetahui bahwa ayat yang bersifat muqayyad tersebut justru lebih mutlak. Ayat muqayyad ini menunjukkan pada praktek riba yang paling tua, yaitu yang berlaku pada masa Jahiliyah. Kemudian setelah itu turunlah ayat yang bersifat mutlak sebagaimana tersebut di atas, yang mengharamkan riba yang sedikit dan riba yang banyak. Sebagaimana ditegaskan dalam al-Qur'an:

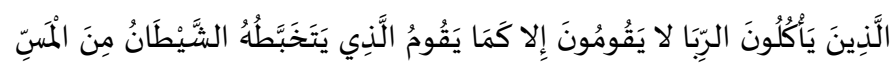

"Orang-orang yang makan (mengambil) riba tidak dapat berdiri melainkan seperti berdirinya orang yang kemasukan syaitan lantaran (tekanan) penyakit gila". ${ }^{48}$

Dengan mengetahui proses atau tahapan yang ditempuh alQur'an dalam menetapkan hukum, maka seorang mufassir tidak akan keliru dalam penafsirannya.

Dalam pandangan M. Quraish Shihab, susunan langkahlangkah sistematis yang dirancang oleh al-Farmawi ini melahirkan dua bentuk dari metode tafsir maud $u^{\prime} i$. Bentuk pertama, ialah penafsiran menyangkut satu surat dalam al-Qur'an dengan menjelaskan tujuan-tujuannya secara umum dan khusus, serta hubungan persoalan-persoalan yang beraneka ragam dalam surat tersebut, sehingga kesemua persoalan saling terkait, bagaikan satu persoalan saja. Kedua, menghimpun ayat-ayat al-Qur'an yang membahas masalah tertentu dari berbagai surat al-Qur'an, kemudian menjelaskan pengertian menyeluruh ayat-ayat tersebut, sebagai jawaban terhadap masalah yang menjadi pokok pembahasannya. $^{49}$

${ }^{48}$ Al-Baqarah: 275

49 M. Quraish Shihab, Membumikan Al-Qur'an, (Bandung: Mizan, 1992), hlm. 117 


\section{Kode Etik Metode Tafsir Maud u’}

Sebelum melakukan penafsiran, seorang mufassir dengan metode maudu $\imath$ harus memperhatikan kode etik dalam penafsiran maự ữ. Șalāh 'Abd al-Fattāh al-Khalidī mengutip pendapat 'Abd al-Sattār al-Sa'id, menjelaskan beberapa hal yang harus diperhatikan oleh seorang penafsir maudu' diantaranya: ${ }^{50}$ Pertama; Memahami secara komprehensif ayat-ayat al-Qur'an sesuai dengan tema yang dibahas. Kedua; Menggunakan riwayat-riwayat hadis yang sahih dalam menjelaskan makna ayatayat yang tengah dikaji. Ketiga; Menjauhkan diri dari fanatisme madzhab, baik dalam bidang teologi (akidah) maupun dalam bidang fikih. Keempat; Meyakini dengan sepenuh hati bahwa semua yang terdapat di dalam al-Qur'an merupakan sesuatu yang haq (mutlak kebenarannya), karena bersumber dari Allah Swt. Kelima; Memahami dengan penuh kesungguhan bahwa al-Qur' an adalah kitab hidayah. Keenam; Mengakui secara benar bahwa alQur'an adalah kitab yang selalu up to date (șâlih li kulli zamān wa makān). Ketujuh; Membekali diri dengan pengetahuan yang mendalam tentang 'uhūm al-Qur'ān. Kedelapan; Memahami ilmuilmu pengetahuan modern, seperti ilmu sejarah, ilmu budaya, filologi, sosiologi, antropologi, psikologi, ilmu politik, ilmu ekonomi, teknologi informasi dan beragam ilmu pengetahuan modern lainnya. Kesembilan; Mengkaji serta meneliti secara serius dan dengan hati yang jernih, tema bahasan yang tengah diteliti sebelum menyimpulkan hasil penelitiannya.

M. Quraish Shihab dalam buku Kaidah Tafsir memberikan catatan untuk para peneliti atau pengkaji al-Qur'an yang akan menggunakan metode tafsir maudu $u$ sebagai berikut: ${ }^{51}$

1) Para penafsir hendaknya pandai-pandai memilih tema yang menyentuh masyarakat dan dirasakan secara langsung kebutuhannya oleh mereka.

2) Para pemula yang menerapkan metode ini seringkali terjerumus dalam kesalahan-kesalahan dalam menerapkannya, antara lain:

${ }^{50}$ al-Khalidi, Al-Tafsīr Al-Maudu'`̀ Bayn Al-Nazariyyah Wa Al-Taṭbīq, hlm. 76-81

${ }^{51}$ M. Quraish Shihab, Kaidah Tafsir, (Tangerang: Lentera Hati, 2013), hlm. 390-391 
a. Menghidangkan uraian ayat demi ayat yang ditelitinya secara berdiri sendiri, padahal seharusnya tidak demikian.

b. Menulis sebab turunnya ayat, arti kosakata, serta munasabah dengan ayat sebelumnya, padahal ini tidak perlu dihidangkan, walau harus dipahami betul oleh sang peneliti.

c. Tidak jarang para pemula memasukkan dalam hidangannya, ide-ide yang benar, namun tidak ada kaitannya dengan ayat-ayat yang dibahas temanya. Mestinya setiap ide yang dihidangkan jelas rujukannya pada ayat-ayat yang dipilih.

Al-Farmawi menegaskan ada sejumlah rambu-rambu yang harus diperhatikan penafsir maudut. Rambu-rambu yang dimaksud adalah ${ }^{52}$ Pertama; Penafsir maudu $\hat{\imath}^{2}$ harus menyadari bahwa dengan metode ini, bukan berarti ia telah sepenuhnya menafsirkan al-Qur'an. Karena al-Qur'an itu sesungguhnya mengandung tujuan-tujuan yang tidak sepenuhnya dapat dicapai manusia. Kedua; Penafsir maudu $\imath$ harus selalu ingat bahwa ia hanya ingin membahas dan mencapai satu masalah bahasan, tidak akan meyimpang dari masalah yang telah ditetapkan, dan tidak melalaikan pembahasan seluruh aspeknya. Ketiga; Penafsir harus memperhatikan tahapan-tahapan al-Qur'an dalam menurunkan hukumnya. Ayat-ayat al-Qur'an itu ada yang turun untuk menjawab sebuah pertanyaan, menyatakan suatu hukum, membantah suatu kebohongan, meringankan suatu hukum yang telah ditetapkan dan menghapus hukum yang sudah ada. Keempat; Di dalam membahas suatu masalah yang sedang dikaji, penafsir maud $u$ issecara konsisten harus menerapkan semua prinsip dan langkah-langkah operasional metode maud $u \hat{\imath}$ ini. Jika tidak, maka ia akan gagal menemukan bentuk masalah seutuhnya seperti yang dimaksudkan oleh al-Qur'an.

\section{Kelebihan dan Kekurangan Metode Tafsir Maudu`}

Sebagaimana ilmu pengetahuan pada umumnya, metode tafsir maudu ìmemiliki sisi kelebihan dan kekurangan. Berikut

${ }^{52}$ al-Farmawi, Metode Tafsir Maudu’i Suatu Pengantar, hlm. 67 
disampaikan beberapa pendapat para ahli tentang kelebihan dan kekurangan metode tafsir maud $u t::^{3}$

a. Kelebihan metode tafsir maudu $u \hat{\imath}$ dapat menjawab tantangan zaman: Permasalahan dalam kehidupan selalu tumbuh dan berkembang sesuai dengan perkembangan kehidupan itu sendiri. Maka metode maudut sebagai upaya metode penafsiran untuk menjawab tantangan tersebut. Untuk kajian tematik ini diupayakan bisa menyelesaikan permasalahan yang dihadapi masyarakat. Praktis dan sistematis: Tafsir dengan metode tematik disusun secara praktis dan sistematis dalam usaha memecahkan permasalahan yang timbul. Dinamis: Metode tematik membuat tafsir al-Qur'an selalu dinamis sesuai dengan tuntutan zaman sehingga menimbulkan image di dalam pikiran pembaca dan pendengarnya bahwa al-Qur'an senantiasa mengayomi dan membimbing kehidupan di muka bumi ini pada semua lapisan dan strata sosial. Membuat pemahaman menjadi utuh: Dengan ditetapkannya juduljudul yang akan dibahas, maka pemahaman ayat-ayat alQur'an dapat diserap secara utuh. Pemahaman semacam ini sulit ditemukan dalam metode tafsir yang dikemukakan di muka. Maka metode tematik ini dapat diandalkan untuk pemecahan suatu permasalahan secara lebih baik dan tuntas.

b. Kelemahan metode maudu lidiantaranya Memenggal ayat alQur'an. yaitu suatu kasus yang terdapat di dalam suatu ayat atau lebih mengandung banyak permasalahan yang berbeda. Misalnya, petunjuk tentang shalat dan zakat. Biasanya kedua ibadah itu diungkapkan bersama dalam satu ayat. Apabila ingin membahas kajian tentang zakat misalnya, maka mau tidak mau ayat tentang shalat harus di tinggalkan ketika menukilkannya dari mushaf agar tidak mengganggu pada waktu melakukan analisis. Membatasi pemahaman ayat: yaitu dengan diterapkannya judul penafsiran, maka pemahaman suatu ayat menjadi terbatas pada permasalahan yang dibahas tersebut. Akibatnya mufassir terikat oleh judul itu. Padahal tidak mustahil satu ayat itu dapat ditinjau dari

${ }^{53}$ Nasharudin Baidan, Metodologi Penafsiran Al-Qur'an, (Yogyakarta: Pustaka Pelajar, 2000), hlm. 165-168 
berbagai aspek, karena ayat al-Qur'an itu bagaikan permata yang setiap sudutnya memantulkan cahaya. Jadi, dengan diterapkannya judul pembahasan, berarti yang akan dikaji hanya satu sudut dari permata tersebut.

\section{Problematika Tafsir Maud ũ̃: Sebuah Catatan Kritis}

Dalam paparan makalahnya, ${ }^{54}$ Aswadi melihat adanya inkonsistensi dari para peneliti tafsir maudu’̌ Di sini Aswadi menyoroti inkonsistensi para mufassir maud $u \hat{\imath}$ dalam menerapkan persyaratan sebab nuzul, tertib nuzul dan munasabahnya. ${ }^{55}$ Dalam aplikasinya, ketentuan tentang sebab nuzul tersebut ternyata tidak memiliki signifikansi secara konprehensip untuk semua ayat alQur'an yang jumlah ayatnya tidak kurang dari 6.234 ayat. Aswadi merujuk pada hasil penelitian Roem Rowi yang menunjukkan bahwa ayat-ayat al-Qur'an yang disertai dengan sebab nuzul hanya berkisar pada 5, 34 \% hingga 11,40\% dari keseluruhan ayat al-Qur'an (Muqbil bin Hadi al-Wadi'i=333 ayat / 5,34 \%, alSuyuti $=711$ ayat $/ 11,40 \%$ dan al-Wahidi $=715$ ayat $/ 11,46 \%$ ). Dengan demikian, kajian tafsir tematik tidak semuanya menerapkan kajian sebab nuzul. Oleh karena itu, kajian tafsir tematik masih memerlukan pendekatan lain yang dipandang lebih konprehensip, termasuk didalamnya adalah memperhatikan aspek tertib nuzul maupun aspek kronologisnya.

Namun demikian, pada aspek tertib nuzul ini pun, Aswadi melihat bahwa dalam aplikasinya masih banyak yang hanya terbatas pada perhatian tata urutan surat-surat dalam al-Qur'an menurut kronologisnya dan belum menembus pada kronologis satuan ayat-ayat yang menjadi fokus kajian. Kajian tafsir tematik yang ada terutama yang menekankan pada kajian tematik laf̧̣̂ belum berdasarkan pada kronologis, baik menurut tata urutan surat maupun ayat-ayat Makkiyyah dan Madaniyyahnya. Karena itu sangat wajar jika dalam aplikasi kajian tafsir tematik lafụi cenderung mengabaikan tata urutan Makiyyah dan Madaniyyahnya, bahkan hampir dapat dipastikan tidak

54 Disarikan dari tulisan Aswadi, Aswadi, "Menggugat Metodologi Tafsir Tematik Konsistensi Antara Teori Dan Aplikasi," n.d. dalam Conference Proceedings AICIS XII di UIN Surabaya

${ }^{55}$ al-Farmawi, Metode Tafsir Maudu'i Suatu Pengantar, hlm. 11 
menyentuh pada kajian munasabah sesuai tertib nuzulnya. Oleh karena itu, kajian munasabah dalam kajian tafsir tematik lafụi berdasarkan kronologis surat, terutama berdasarkan tata urutan ayat-ayat Makiyyah dan Madaniyyahnya patut mendapat perhatian serius, sehingga munasabah yang selama ini hanya berkembang sesuai tata urutan mushaf, juga bisa dikembangkan pada kajian munasabah berdasarkan tata urutan kronologisnya.

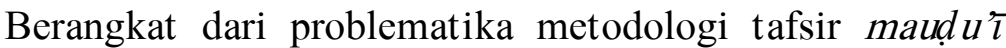
tersebut di atas, Aswadi kemudian menekankan pentingnya kajian tafsir tematik berdasarkan kronologis yang mengarah pada konsistensi antara teori dan aplikasi melalui integrasi format kronologi berdasarkan tata urutan surat dan satuan ayat Makiyyahdan Madaniyyahnya beserta munasabah dan berbagai temuan dan kesimpulan secara simultan dan proporsional.

Guna mendukung pendapatnya, Aswadi kemudian mengkritisi dengan mengambil contoh tafsir Jalaluddin Rakhmat yang menawarkan prinsip-prinsip komunikasi dengan melacak kata kunci (key-concept) yang digunakan oleh al-Qur'an untuk komunikasi dengan merujuk pada kata al-qawl. Menurutnya dengan memperhatikan kata "qawl' dalam konteks perintah (amr) dapat melahirkan enam prinsip komunikasi, yakni qawlan sadidan (QS. 4: 9); 33: 70) ${ }^{56}$; qawlan bahghan (QS. 4: 63) ;7 $^{57}$ qawlan maysūran (QS. 17: 28) ${ }^{58}$, qawlan layyinan (QS. 20: 44) ${ }^{59}$; qawlan kan̄man (QS. 17: 23) ${ }^{60}$; qawlan ma'nūfan (QS. 4: 5) ${ }^{61}$.

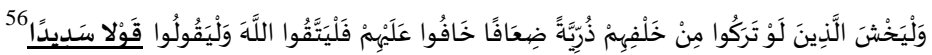

Artinya: "Dan hendaklah takut kepada Allah orang-orang yang seandainya meninggalkan dibelakang mereka anak-anak yang lemah, yang mereka khawatir terhadap (kesejahteraan) mereka. Oleh sebab itu hendaklah mereka bertakwa kepada Allah dan hendaklah mereka mengucapkan perkataan yang benar". (QS. An-Nisa: 9)

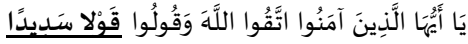

"Hai orang-orang yang beriman, bertakwalah kamu kepada Allah dan katakanlah perkataan yang benar". (Q.S. Al-Ahzab: 70)

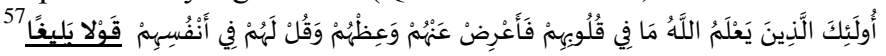

"Mereka itu adalah orang-orang yang Allah mengetahui apa yang di dalam hati mereka. Karena itu berpalinglah kamu dari mereka, dan berilah mereka pelajaran, dan katakanlah kepada mereka perkataan yang berbekas pada jiwa mereka". (Q.S. an-Nisa: 63)

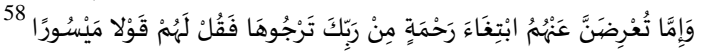


Struktur dan tata urutan kata kunci yang terkait dengan "qawl' dengan berbagai bentuknya di atas tampak tidak terikat oleh tata urutan secara kronologis, baik menurut surat maupun Makiyyah dan Madaniyyahnya sebagaimana yang dimaksudkan oleh Izzah Darwazah berdasarlan urutan surat menurut kronologisnya dan tidak disebutkan pula status Makiyyah dan Madaniyyahnya sebagaimana yang disyaratkan oleh al-Farmawi maupun lainnya.

Oleh karena itu, Aswadi kemudian menunjukkan bahwa pencarian kata "qawl" dan yang terkait dengannya, semestinya dapat dilacak melalui Mu'jam al-Mufahras li Alfăz al-Qur'ān yang dikonversikan dengan tata urutan surat-surat dalam alQur'an sebagaimana yang ditawarkan oleh 'Izzah Darwazah. Dengan cara demikian, maka data yang diperoleh kemudian dapat diklasifikasikan pada dua kelompok, yaitu Makiyyah dan Madaniyyahnya. Kelompok Makiyyah terkait dengan a) QS. alMuzzammil [83]: 5 -qawlan tsaqila; b) QS. Țāha [20]: 44 -qawlan layyinan; c) QS. al-Isrā' [17]: 23 -qawlan kan̄mā; d) QS. al-Isrā' [17]: 28 -qawlan maisūrā. Kelompok Madaniyyah terkait dengan

"Dan jika kamu berpaling dari mereka untuk memperoleh rahmat dari Tuhanmu yang kamu harapkan, maka katakanlah kepada mereka ucapan yang pantas”. (Q.S. Al-Isaa: 28)

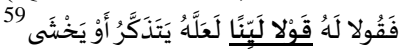

"maka berbicaralah kamu berdua kepadanya dengan kata-kata yang lemah lembut, mudah-mudahan ia ingat atau takut." (Q.S. Thahaa: 44)

$606 َ$

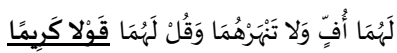

"Dan Tuhanmu telah memerintahkan supaya kamu jangan menyembah selain Dia dan hendaklah kamu berbuat baik pada ibu bapakmu dengan sebaikbaiknya. Jika salah seorang di antara keduanya atau kedua-duanya sampai berumur lanjut dalam pemeliharaanmu, maka sekali-kali janganlah kamu mengatakan kepada keduanya perkataan "ah" dan janganlah kamu membentak mereka dan ucapkanlah kepada mereka perkataan yang mulia". (Q.S. Al-Israa: 23)

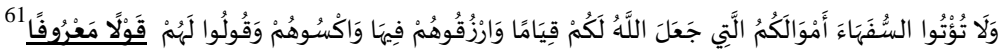

"Dan janganlah kamu serahkan kepada orang-orang yang belum sempurna akalnya, harta (mereka yang ada dalam kekuasaanmu) yang dijadikan Allah sebagai pokok kehidupan. Berilah mereka belanja dan pakaian (dari hasil harta itu) dan ucapkanlah kepada mereka kata-kata yang baik". (Q.S. An-Nisa: 5) 
a) QS. al-Baqarah [2]: 235 qawlan ma'nū fă; b) QS. al-Aḥzāb [33]: 70 qawlan sadi dan; c) QS. al-Nisā' [4]: 63 qawlan balighan.

Secara sederhana, pesan yang terkandung pada tata urutan secara kronologis tersebut dapat digambarkan secara berurutan bahwa tahap-tahap penyampaian pesan al-Qur'an berawal dari qawlan thaqulan -pesan yang berkualitas, yang harus disampaikan dengan qawlan layyinan -penuh kelembutan; qawlan kariman penuh hormat; qawlan maisuran -penuh kemudahan; qawlan ma'nüfan -penuh kearifan lokal; qawlan sadidan -mengandung kebenaran; dan qawlan batighan -sebagai akhir dari proses penyampaian pesan yang benar-benar dapat menembus secara efektif pada obyek yang menjadi sasaran.

\section{Tafsir Tentang Lingkungan: Sebuah Model Aplikatif}

Sebagai contoh aplikasi tafsir maudu ìini, berikut disampaikan tulisan karya Mujiyono Abdillah yang konsen menyoroti masalah lingkungan. Pemikirannya yang cukup apik ditampilkan dalam karya disertasinya yang kemudian terbit dengan judul: Agama Ramah Lingkungan: Perspektif Al-Qur'an. ${ }^{62}$ Dalam karyanya tersebut Mujiyono menemukan konsep lingkungan diperkenalkan oleh al-Qur'an dengan beragam istilah. Beberapa kata yang digunakan al-Qur'an antara lain al-Ālamīn (seluruh spesies), al-samā(ruang waktu), al-ardl (bumi), dan al$b \bar{l}$ 'ah (lingkungan).

a. Al-Alamin (seluruh spesies)

Kata al-alamin disebutkan dalam al-Qur'an sebanyak 73 kali baik dalam bentuk frase (idlofiyah) ataupun berupa gabungan kata (syibhu jumlah). Mujiyono Abdillah menemukan bahwa dari jumlah tersebut tidak semuanya berkonotasi pada seluruh spesies, ada juga yang berkonotasi makhluk berakal (manusia). ${ }^{63}$ Temuan tersebut berbeda dengan pendapat Sirajuddin Dzar yang menyatakan bahwa kata alalamin dalam al-Qur'an hanya berkonotasi makhluk berakal

62 Mujiyono Abdillah, Agama Ramah Lingkungan: Perspektif AlQur'an, (Jakarta: Paramadina, 2001), hlm. 32

63 Mujiyono Abdillah, Agama Ramah Lingkungan: Perspektif AlQur'an, hlm. 34 
yakni manusia saja. ${ }^{64}$ Lebih lanjut Mujiyono menjelaskan bahwa kata al-alamin ditempatkan dalam frase possesif (idlofiyah milkiyah) sebagai mudlof kata Tuhan (rabbun) atau kata depan $l i$ dan 'an dan yang lain justru berarti seluruh spesies, bukan berarti hanya spesies manusia saja.

Kata al-alamin yang berkonotasi seluruh spesies disebutkan dalam al-Qur'an sebanyak 46 kali. Lima kali di antaranya berupa gabungan kata dengan kata depan. Sedangkan selebihnya atau sebanyak 41 kali berupa frase possesif, yaitu dalam frase rabbun al-'alamin.

Penyebutan kata al-alamin yang digabungkan dengan kata depan li, 'an, ala terdapat pada QS. Al-Baqarah [2]: 251, QS. Ali Imran [3]: 37, 106, QS. Al-Ankabut [29]: 6, dan QS. Ash-Shaffat [37]: 79. Semua kata al-alamin yang digabungkan dengan kata depan sebagaimana terdapat dalam ayat-ayat alQur'an di atas semuanya berkonotasi alam semesta atau seluruh spesies. Hal itu didasarkan pada konteks wicaranya yang tidak hanya berkaitan dengan manusia, tetapi berkaitan dengan seluruh spesies. Hal ini menunjukkan bahwa al-Qur'an memperkenalkan term lingkungan dengan menggunakan term seluruh spesies (al-alamin). Meskipun secara faktual kata alalamin juga digunakan al-Qur'an untuk pengertian khusus spesies manusia. Pemaknaan untuk dua konotasi demikian tergant ung pada konteks wicara kalimatnya.

Adapun sebaran kata al-alamin yang berposisi sebagai kata kedua (mudlaf ilaih) dari kata Tuhan (rabbun alamin) terdapat pada QS. Al-Fatihah [1]: 2, QS. Al-Baqarah [2]: 131, QS. [5]: 28, QS. [6]: 45, 71, 162, QS. [7]: 54, 61, 67, 104, 121, QS. [10]: 10, 37, QS. [26]: 16, 23,47, 77, 97, 109, 127, 145, 164, 180, 192, QS. [27]: 8, 44, QS. [28]: 30, QS. [32]: 2, QS. [37]: 79, 87, 182, QS. [39]: 75, QS. [40]: 64, 65, 66, QS. [41]: 9, QS. [43]: 46, QS. [45]: 36, QS. [56]: 80, QS. [69]: 43, QS. [81]: 29, QS. [83]: $6 .{ }^{65}$ Berdasarkan data yang ada, frase rabbu al-alamin seluruhnya digunakan untuk konotasi Tuhan seluruh

${ }^{64}$ Sirajjuddin Dzar, Konsep Penciptaan Alam Pemikiran Islam, Sains Dan Al-Qur'an, (Jakarta: Raja Grafindo Persada, 1994), hlm. 19

${ }^{65}$ Muhammad Fuad al-Baqi, "Al-Mu'jam Al-Mufakhras Li Alfazh AlQur'an”, (Mesir: Dar al-Fikr, 1992), hlm. 609-611 
alam semesta atau Tuhan seluruh spesies. Baik spesies biotik maupun abiotik yang meliputi spesies manusia, binatang, tumbuh-tumbuhan, mikroba, mineral dan lainnya.

Untuk mendapatkan gambaran lebih jelas tentang penafsiran rabbu al-alamin dengan konotasi Tuhan seluruh alam semesta adalah tafsir surat QS. al-Fatihah [1]: 2.

$$
\text { الْحَمْدُ لِلَّلَهِ رَبِّ الْعَالَمِينَ }
$$

"segala puji bagi Allah, Tuhan semesta alam".

Kata $R a b b$ (tuhan) berarti: Tuhan yang ditaati yang Memiliki, Mendidik dan Memelihara. Lafal Rabb tidak dapat dipakai selain untuk Tuhan, kecuali kalau ada sambungannya, seperti rabbu al-bait (tuan rumah). Sedangkan kata 'Alamiin (semesta alam): semua yang diciptakan Tuhan yang terdiri dari berbagai jenis dan macam, seperti: alam manusia, alam hewan, alam tumbuh-tumbuhan, benda-benda mati dan sebagainya. Allah Pencipta semua alam-alam itu.

Isu sentral ayat di atas adalah kata rabbu al-alamin. Kata tersebut merupakan bentuk aneksi possesif yang terdiri dari kata rabbun sebagai kata pertama (Mudlof), dan kata alalamin sebagai kata kedua (mudlof ilaih). Kata rabbun merupakan bentuk mashdar dari kata rabba - yarubbu - rabban yang berarti pemilik, pendidik, pemelihara. Kata ini merupakan salah satu nama baik dan predikat khusus bagi Allah swt. bahkan kata tersebut hanya digunakan untuk Tuhan semata kecuali dalam keadaan khusus, seperti rabbu al-bait (pemilik rumah), rabbu al-jamal (pemilik unta) dan sebagainya. ${ }^{66}$ Sedangkan kata al-alamin merupakan bentuk jamak dari kata 'alam yang berarti nama, dunia, organisme dan spesies. ${ }^{67}$ Sehingga kata al-alamin bisa diartikan banyak organisme atau seluruh spesies yang meliputi seluruh spesies biotik (manusia, binatang, mikroba) dan spesies abiotik (tumbuh-tumbuhan, benda mati, mieral, biospher dan lain-lain).

Sedangkan kata al-Alamin yang berkonotasi makhluk berakal yakni spesies manusia diungkapkan dalam al-Qur'an sebanyak 25 kali. Sebaran kata tersebut terdapat pada QS. Al-

${ }^{66}$ Ibn Manzur, Lisan Al- 'Arab, Jilid V: hlm. 224

${ }^{67}$ Ibn Manzur, Lisan Al- 'Arab, Jilid V: hlm. 216 
Baqarah [2]: 37, 122, QS. Ali Imran [3]: 33, 42, 97, QS. AlMaidah [5]: 20, 115, QS. Al-An'am [6]: 66, 90, QS. Al-A'raf [7]: 140, QS. Yusuf [12]: 104, QS. Al-Hijr [15]: 70, QS. AlAnbiya' [21]: 71, 91, 107, QS. Al-Furqan [25]: 1, QS. AsySyu'ara [26]: 165, QS. Al-Ankabut [29]: 15, 28, QS. AshShafat [37]: 79, QS. Shad [38]: 87, QS. Ad-Dukhan [44]: 32, QS. Al-Jatsiyah [45]: 16, QS. Al-Qalam [68]: 52, dan QS. AshShaf [61]: $27 .{ }^{68}$

Kedua puluh lima ayat tersebut menyebutkan kata alalamin dengan menggabungkannya dengan beberapa kata depan (huruf/ahruf), yakni kata depan 'ala, li, 'an, dan min. Kata al-alamin yang digabungkan dengan kata depan 'ala sebagaimana terdapat dalam QS. Al-Baqarah [2]: 47:

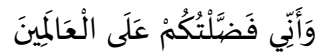

“...dan (ingatlah pula) bahwasanya aku telah melebihkan kamu atas segala umat."

Kata al-alamin yang digabungkan dengan kata depan $l i$ seperti terdapat pada QS. Ali Imran [3]: 96.

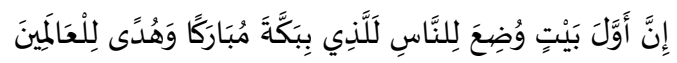

"Sesungguhnya rumah yang mula-mula dibangun untuk (tempat beribadat) manusia, ialah Baitullah yang di Bakkah (Mekah) yang diberkahi dan menjadi petunjuk bagi semua manusia."

Kata al-alamin yang digabungkan dengan kata depan 'an seperti terdapat pada QS. Ali Imran [3]: 97.

$$
\text { فَإِنَّ اللَّهَ غَغِيٌْ عَنِ الْعَالمَينَ }
$$

"Maka Sesungguhnya Allah Maha Kaya (tidak memerlukan sesuatu) dari semesta alam."

Kata al-alamin yang digabungkan dengan kata depan min seperti terdapat pada QS. Al-A'raf [7]: 80.

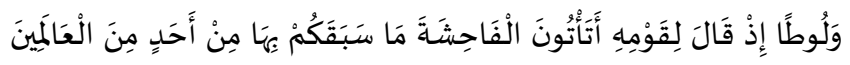

"Dan (Kami juga telah mengutus) Luth (kepada kaumnya). (Ingatlah) tatkala dia berkata kepada mereka: Mengapa kamu mengerjakan perbuatan keji itu, yang belum pernah dikerjakan oleh seorangpun (di dunia ini) sebelummu?"

${ }^{68}$ al-Baqi, “Al-Mu'jam al-Mufakhras Li al-fazh al-Qur'an”, hlm. 177 
Beberapa ayat di atas menunjukkan bahwa lawan bicara yang paling tepat adalah untuk arti spesies manusia sebagai makhluk berakal (rational species). Hal ini menjadi indikator yang mengisyaratkan kata al-alamin berkonotasi spesies manusia sebagai makhluk berakal. Adapun kata kunci yang digunakan dalam konteks wicaranya antara lain kata hudan (hidayah), dzikron (peringatan), shudur (nurani), rasulan (risalah), dan sebagainya. Kata-kata tersebut hanya digunakan untuk spesies manusia dan tidak lazim digunakan untuk selain manusia. Karena manusia merupakan spesies berakal dan berhati nurani yang dapat berkomunikasi untuk kepentingan hidayah, risalah, dan kata hati.

b. Al-Sama (ruang jagad raya)

Kata as-sama digunakan al-Qur'an untuk memperkenalkan jagad raya. Turunannya dalam bentuk jamak adalah as-samawat. Secara keseluruhan kata as-sama dan turunannya disebutkan dalam al-Qur'an sebanyak 387 kali. Kata tersebut hadir dalam bentuk tunggal (mufrad) sebanyak 210 kali dan dalam bentuk jamak disebut 177 kali. Secara etimologi kata as-sama dan turunannya berasal dari kata sama, yasmu, sumuwan, wa sama'an yang berarti meninggi, menyublim, dan sesuatu yang tinggi. Sedangkan secara terminologis, kata as-sama dan turunannya berarti langit, jagad raya, ruang angkasa dan ruang waktu. ${ }^{69}$

Kata as-sama dan turunannya yang berkonotasi jagad raya sebagaimana terdapat dalam QS. Al-Baqarah [2]: 22 sebagai berikut:

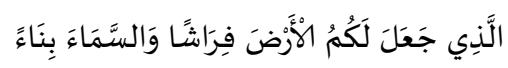

"Dialah, (Tuhan) yang menjadikan bumi sebagai hamparan bagimu dan langit (jagad raya) sebagai atap (ruangan) bagimu..."

Kata as-sama yang berkonotasi ruang udara sebagaimana terdapat dalam QS. An-Nahl [16]: 79 sebagai berikut:

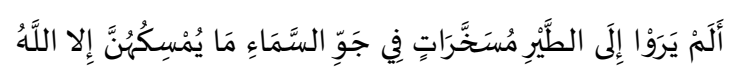

\footnotetext{
${ }^{69}$ Manzur, Lisan Al- 'Arab, Jilid VIII. hlm. 79
} 
"Tidakkah mereka memperhatikan burung-burung yang dimudahkan terbang diangkasa bebas, tidak ada yang menahannya selain dari pada Allah..."

Kata as-sama yang berkonotasi ruang angkasa sebagaimana terdapat pada QS. Al-Furqan [25]: 61, sebagai berikut:

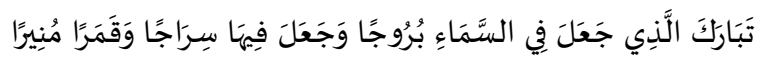

"Maha suci Allah yang menjadikan di langit gugusan-gugusan bintang dan Dia menjadikan juga padanya matahari dan bulan yang bercahaya."

Secara keseluruhan, variasi konotasi makna kata assama yang terdapat dalam al-Qur'an mengacu pada alam jagad raya. Karena jagad raya terdiri dari ruang udara atau biospher dan ruang angkasa atau lithosphere dan statospher. Sehingga dapat dikatakan bahwa jagad raya yang meliputi ruang atmosphere dan biospher merupakan salah satu term yang digunakan al-Qur'an untuk mengungkap istilah lingkungan. Sebab, secara faktual lingkungan jagad raya hakikatnya terdiri dari ruang udara atau atmosfer dan ruang angkasa atau spacepher.

c. Al-Ardl (bumi)

Kata al-ardl disebutkan dalam al-Qur'an sebanyak 463 kali, baik hadir secara sendirian atau digabungkan dengan kata tugas. Sebaran kata al-ardl dalam al-Qur'an memiliki dua variasi makna. Pertama, bermakna lingkungan planet bumi yang sudah jadi dengan konotasi tanah sebagai ruang tempat organisme atau jasad renik, wilayah tempat kehidupan manusia dan fenimena geologis. Kedua, bermakna lingkungan planet bumi dalam proses menjadi yakni proses penciptaan dan kejadian planet bumi. Untuk kepentingan perumusan konsep lingkungan tampaknya konotasi yang pertama yakni lingkungan bumi yang sudah jadi dapat membantu memperjelas dan mempertegas konsep. Sedangkan untuk kata al-ardl dalam konotasi proses penciptaan lingkungan lebih tepat jika digunakan untuk kepentingan kajian filosofis.

Beberapa ayat yang menggunakan kata al-ardl dengan berbagai konotasinya dalam al-Qur'an antara lain: 
1. Berkonotasi niche ekologis bumi, sebagaimana dalam QS. Al-Baqarah [2]: 164:

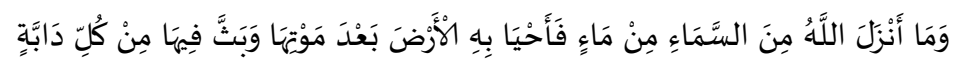

"dan apa yang Allah turunkan dari langit berupa air, lalu dengan air itu Dia hidupkan bumi sesudah mati (kering)-nya dan Dia sebarkan di bumi itu segala jenis hewan (satwa)..."

2. Berkonotasi lingkungan hidup, sebagaimana dalam QS. AlBaqarah [2]: 22.

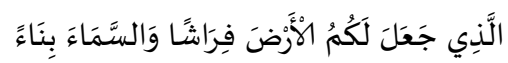

"Dialah yang menjadikan bumi sebagai hamparan bagimu dan langit sebagai atap..."

Demikian juga pada QS. Al-A'raf [7]: 24 sebagai berikut:

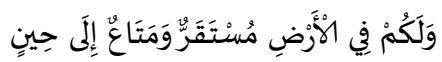

"dan kamu mempunyai tempat kediaman dan kesenangan (tempat mencari kehidupan) di muka bumi sampai waktu yang telah ditentukan".

Ayat lain adalah QS. Ibrahim [14]: 14 sebagai berikut:

$$
\text { وَلَنْسُكِنَنَكُمُمُ الْْرَضَضَ مِنْ بَعْدِهِمْ }
$$

"dan Kami pasti akan menempatkan kamu di negeri-negeri itu sesudah mereka."

Kata al-ardl pada ayat di atas bermakna negeri-negeri yang dapat dipahami sebagai lingkungan.

3. Berkonotasi ekosistem bumi, sebagaimana dalam QS. AnNahl [16]: 15 sebagai berikut:

$$
\text { وَأَلْقَى فِي الأرْضِ رَوَاسِيَ أَنْ تَمِيدَ بِكُمْ }
$$

"dan Dia menancapkan gunung-gunung di bumi supaya bumi itu tidak goncang bersama kamu..."

Terjemahan ayat di atas dapat dipahami bahwa Allah menciptakan gunung sebagai penyangga keseimbangan ekosistem bumi dan manusia.

4. Berkonotasi daur ulang dalam ekosistem bumi, sebagaimana dalam QS. Hajj [22]: 5 sebagai berikut:

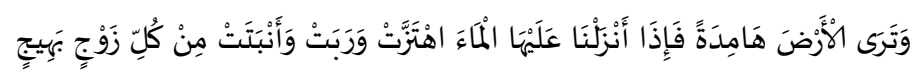


"dan kamu Lihat bumi ini kering, kemudian apabila telah Kami turunkan air di atasnya, hiduplah bumi itu dan suburlah dan menumbuhkan berbagai macam tumbuh-tumbuhan yang indah."

Terjemahan ayat tersebut di atas dapat dipahami manusia diperintahkan untuk mengamati daur ulang bumi, yang semula kering disiram air kemudian menjadi subur dan tumbuh berbagai macam tanaman yang segar dan indah.

Dari beberapa ayat yang disebutkan di atas, makna semantik kata al-ardl yang terdapat dalam al-Qur'an digunakan sebagai salah satu istilah untuk memperkenalkan istilah lingkungan. Dalam hal ini kata al-ardl digunakan dalam konotasi ekosistem, niche ekologis, lingkungan hidup dan habitat. Keseluruhan konotasi tersebut mengacu pada term lingkungan dalam konsep ekologis. Sehingga dapat dikatakan bahwa kata al-ardl tersebut digunakan al-Qur'an untuk menunjuk makna lingkungan. Ini sejalan dengan tradisi masyarakat ekologis yang lazim menyebut istilah lingkungan untuk arti planet bumi.

d. Al-bi'ah (lingkungan sebagai ruang kehidupan).

Al-Qur'an menggunakan kata al-bi'ah untuk memperkenalkan konsep ligkungan sebagai ruang kehidupan. Kata ini merupakan turunan dari kata ba'a, yabi'u, bi'atan, yang memiliki arti kembali, menempati wilayah, ruang kehidupan dan lingkungan. ${ }^{70}$ Secara keseluruhan al-Qur'an menyebutkan kata al-bi'ah sebanyak 18 kali yang tersebar dalam 15 ayat. ${ }^{71}$ Penyebutan kata al-bi'ah tersebut tidak selalu berkonotasi lingkungan sebagai ruang kehidupan. Adapun yang berkonotasi lingkungan sebagai ruang kehidupan antara lain terdapat dalam:

QS. Ali Imran [3]: 121 sebagai berikut:

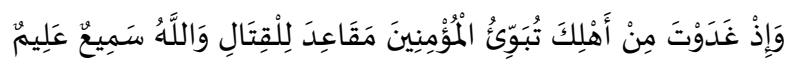

"dan (ingatlah), ketika engkau (Muhammad) berangkat pada pagi hari meninggalkan keluargamu untuk mengatur orang beriman pada pos-pos pertempuran...

${ }^{70}$ Manzur, Lisan Al- 'Arab, Jilid VIII. hlm. 27

${ }^{71}$ al-Baqi, “Al-Mu'jam Al-Mufakhras Li Alfazh Al-Qur'an”, hlm. 177 
QS. Al-A'raf [7]: 74 sebagai berikut:

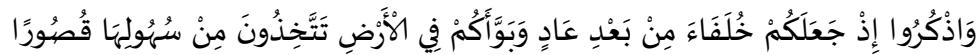

"dan ingatlah ketika Dia menjadikan kamu khalifah-khalifah setelah kaum "Ad dan menempatkan kamu di bumi. Ditempat yang datar kamu dirikan istana-istana..."

Kata wabawwaakum pada ayat tersebut bermakna menjadikan bumi sebagai lingkungan ruang kehidupan.

QS. Yunus [10]: 93 sebagai berikut:

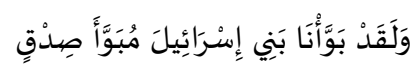

"dan sungguh, Kami telah menempatkan Bani Israil di tempat kediaman yang bagus..."

Kalimat menempatkan di tempat yang bagus juga mengandung konotasi makna memberikan lingkungan sebagai ruang kehidupan yang ideal.

QS. Yusuf [12]: 56 sebagai berikut:

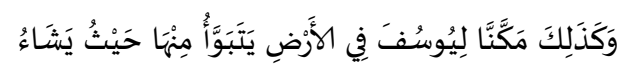

"dan demikianlah kami memberi kedudukan kepada Yusuf di negeri ini [Mesir] untuk tinggal di mana saja ia kehendaki..."

Ayat di atas mengandung makna Yusuf bebas menempati lingkungan (yatabawwa'u) di mana saja di negeri Mesir.

QS. An-Nahl [16]: 41 sebagai berikut:

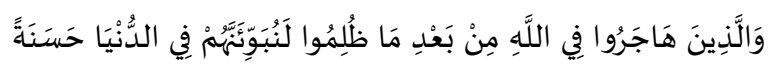

"dan orang yang berhijrah karena Alloh setelah mereka di zalimi, pasti kami memberi tempat yng baik kepada mereka di dunia..."

Ayat di atas mengandung makna bahwa para imigran diberi fasilitas lingkungan tempat tinggal yang nyaman.

QS. Al-Ankabut [29]: 58 sebagai berikut:

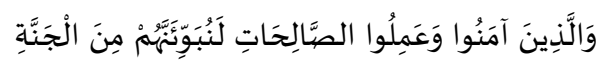

"dan orang-orang yang beriman dan mengerjakan kebajikan, sungguh mereka akan Kami tempatkan pada tempat-tempat yang tinggi (di dalam surga)". 
Pemaknaan secara konotatif adalah orang-orang yang beriman dan produktif (melakukan amal kabajikan) akan diberikan lingkungan tempat tinggal yang ideal di surga.

Nampak bahwa kata al-bi'ah yang disebutkan dalam beberapa ayat di atas berkonotasi pada lingkungan sebagai ruang kehidupan khususnya manusia. Hal ini menunjukkan bahwa al-Qur'an telah memperkenalkan konsep lingkungan sebagai ruang kehidupan yang selaras dengan konsep ekologi modern.

Dari hasil pembacaannya tersebut, Mujiyono Abdillah kemudian menyimpulkan bahwa konsep lingkungan hidup menurut al-Qur'an adalah lingkungan dalam arti luas yakni meliputi lingkungan alam planet bumi, ruang angkasa dan angkasa luar. Lingkungan dipahami tidak hanya meliputi lingkungan hidup manusia, tetapi lingkungan hidup seluruh spesies baik yang ada di ruang bumi maupun di ruang angkasa bahkan ada yang di ruang angkasa luar. Keseimbangan ekosistem di ruang bumi berhubungan dengan ekosistem di luar ruang bumi. Sehingga menurut ajaran Islam manusia wajib menjaga kelestarian daya dukung lingkungan bukan saja dalam lingkungan planet bumi, tetapi juga di angkasa luar serta luar angkasa. ${ }^{72}$

\section{E. Kesimpulan}

Berdasarkan kajian di atas dapat disimpulkan bahwa metode tafsir Maudlu'i memiliki peran penting dalam memahami isi kandungan al-Qur'an. Sebagai sebuah metode penafsiran, kehadiran metode tafsir maudu $u \grave{\imath}$ ini mampu mentransmisikan makna yang dikandung dalam ayat-ayat al-Qur'an kepada pembacanya. Dengan model pembahasannya yang tematik, pembaca lebih bisa memahami suatu masalah (tema) secara komprehensif. Dan pada gilirannya metode ini diharapkan mampu mendialogkan al-Qur'an dengan pembacanya dalam semua konteks kehidupannya.

Meskipun demikian, sebagai bagian dari produk budaya (ilmu pengetahuan), metode tafsir maud $u \imath$ tidak lepas dari adanya penilaian positif dan negatif. Oleh karena itu, sisi kelebihan

\footnotetext{
${ }^{72}$ Abdillah, Agama Ramah Lingkungan: Perspektif Al-Qur'an, hlm. 50
} 
metode ini bisa terus digunakan untuk menggali lautan makna alQur'an. Sementara sisi kekurangannya dijadikan sebagai bahan untuk mengembangkan ilmu tafsir itu sendiri, sehingga ilmu tafsir akan terus bergerak dinamis seiring dengan perkembangan ummat manusia.

\section{DAFTAR PUSTAKA}

Abdillah, Mujiyono. Agama Ramah Lingkungan: Perspektif AlQur'an. Jakarta: Paramadina, 2001

Ak, Khālid 'Abdurrahmān al-'. Al-Furqān Wa Al-Qur'ān,. Beirut: Dār al-Hikmah, t.th.

Aswadi. "Menggugat Metodologi Tafsir Tematik Konsistensi Antara Teori Dan Aplikasi," n.d.

Baidan, Nasharudin. Metodologi Penafsiran Al-Qur'an. Yogyakarta: Pustaka Pelajar, 2000.

Baqi, Muhammad Fuad al-. "Al-Mu'jam Al-Mufakhras Li Alfazh Al-Qur'an.” Mesir: Dar al-Fikr, 1992.

Daghamin, Ziyad Khalil Muhammad al-. Manhajiyyat Al-Bahth Fi Al-Tafsir Al-Mawdu'i Al-Qur'an Al-Karim. Amman: Dar al-Bashir, 1995.

Darraz, Muhammad 'Abd Allah al-. Al-Naba' Al-'Azim,. Alexandria: Dar al-Murabitun, 1997.

Dhahabi, Muhammad Husayn al-. Al-Tafsir Wa Al-Mufassirun. 6.th. Vol. Vol. 1. Cairo: Maktabah Wahbah, 1995. 
Dzar, Sirajjuddin. Konsep Penciptaan Alam Pemikiran Islam, Sains Dan Al-Qur'an. Jakarta: Raja Grafindo Persada, 1994.

Farmawi, Abd. al-Hayy al-. Metode Tafsir Maudu'i Suatu Pengantar. Translated by Suryan A. Jamrah. Jakarta: PT. Raja Grafindo Persada, 1996.

Ghazali, Muhammad al-. Nahw Tafs'ir Mawdu'i Li Suwar AlQur'an. Beirut: Dar al-Syuruq, 2002.

Ibn Manzur. Lisan Al- 'Arab. Vol. Jilid V. Beirut: Dar Sadir, 1990. Ibn'Ashur, Muhammad Thahir. Al-Tahrir Wa Al-Tanwir. Juz I. Tunis: Dar al-Tunisiyah, tt.

Jansen, J.J.G. The Interpretation of the Qur'an in Modern Egypt. 2nd ed. Leidin: E.J. Brill, 1980.

Khalidi, Salah 'Abd al-Fatah al-. Al-Tafsìr Al-Maudu’ Bayn AlNazariyyah Wa Al-Tatbìq. Jordan: Dar al-Nafas'is, 2001.

Marbawi, Muhammad Idris al-. "Kamus Al- Marbawi." Mesir: Mushthafa al-Babi al-Halabi, H 1350.

Muslim, Mustafa. Mabahith Fi Al-Tafsir Al-Mawdu'i. Dimashq: Dar al-Qalam, 2000.

Nawawi, Rif'at Syaukani. Rasionalitas Tafsir Muhammad Abduh: Kajian Masalah Akidah Dan Ibadat. Jakarta: Paramadina, 2002.

Qattan, Manna' al-. Mabahith Fi “Ulum Al-Qur”an. tt: ttp, tth.

Qutb, Sayyid. Fl Zilal Al-Qur'an. Beirut: Dar al-Syuruq, 1987.

Rahman, Fazlur. Major Themes of The Qur'an. 2nd ed. Kuala Lumpur: Islamic Book Trust, 1999.

Shihab, M. Quraish. Kaidadh Tafsir. Tangerang: Lentera Hati, 2013.

Membumikan Al-Qur'an. Bandung: Mizan, 1992.

Umari, Ahmad Jamal al-. Dirasat Fi Al-Tafsir Al-Mawdu'i Li AlQosos Al-Qur'ani. 2nd ed. Cairo: Maktabat al-Khanji, 2001. 
Fauzan, Imam Mustofa \& Masruchin

Zarkashi, Burhan al-Din al-. Al-Burhan Fi "Ulum Al-Qur"an, Ibrahim Muhammad Abu Fadl (Ed). Vol. 3. Beirut: alMaktaba al-'Airiyyah, tt.

Zarqani, 'Abd al-'Azhim al-. Manahil Al-'Irfan Fi "Ulum AlQur”an. Jilid II. Kairo: Dar Ihya al- Kutub al-‘Arabiyah, tt. 